\title{
Knowledge is power: In a world shaped by science, what obligation do scientists have to the public?
}

\author{
Elizabeth Halliday*
}

Woods Hole Oceanographic Institution, Redfield 3-24, MS\# 32, Woods Hole, Massachusetts 02540, USA

\begin{abstract}
Since beginning my graduate studies in science, I have occasionally found myself struggling to find the right words to explain exactly what it is I do, and why it matters, to non-scientist family and friends. The difficulty of 'translating' science highlights one of the incongruities between scientists and the public in society today: the general public claims interest in science and science news, despite having only a tenuous understanding of basic science concepts, while scientists, although generally eager to share knowledge, resent oversimplification and fear misrepresentation in the popularization of their work. In this article, I address the extent of the scientist's responsibility to enhance scientific understanding of the public, and attempt to reconcile an understanding of what the public needs or desires from scientists with what researchers are actually trained to do.
\end{abstract}

KEY WORDS: Science literacy · Science communication · Science journalism · Graduate education

\section{INTRODUCTION}

A subset of scientists can skillfully translate the excitement and beauty of their research into a common language enjoyed by the public. They stand out as spokespeople for science who can elegantly parlay a scientific vision of the universe to readers who have a limited scientific background. These spokespeople are few and far between, for despite a general consensus among scientists that the public should be informed of our current understanding of the natural world and how it works, 'spokesperson' is a job that the majority of researchers do not aspire to. Scientists must invest considerable time and energy into publishing their results in the peer-reviewed literature - the seal of approval for scientific studies and the standard of achievement for scientists. The problem, from a public perspective, is that this body of literature does not disseminate information to people beyond a specific field of interest-it is frequently so technical that even other scientists may be excluded (Kennedy 2007).

This raises a practical concern: the exclusivity of the scientific publishing and rewards system may adversely affect the scientific literacy of the public, and thereby negatively impact decisions regarding funding for basic research, management of environmental resources, or support for science education. It is broadly agreed that a scientifically literate public is necessary in the modern world for making informed personal decisions and meaningfully participating in democratic processes. The National Science Board (NSB 2008, p. 15-16) describes scientific literacy as 'knowing basic facts and concepts about science and having an understanding of how science works,' and further explain in the introduction of their 2008 report on Science and Technology (S\&T) Indicators in America,

Americans need to comprehend common scientific and technological terms such as DNA or molecule and recall commonly cited facts so they can make sense of what they read and hear about S\&T-related matters. Whether they turn their attention to congressional debates over stem cell research or to instructional videos or pamphlets explaining how to use a newly purchased electronic device, the messages they get presuppose some basic knowledge of terms, concepts, and facts.

Heinz Pagels (1989), a gifted physicist and writer, insightfully summarized the role science must play in societal decisions: 'Science cannot resolve moral conflicts, but it can help to more accurately frame the 
debates about those conflicts.' What role should scientists have in communicating their findings beyond the scientific literature, and in improving scientific literacy in general?

\section{THE CURRENT STATE OF SCIENTIFIC LITERACY IN AMERICA}

Science literacy surveys conducted since 1979 show that Americans are able to correctly answer only about half of the basic true-false science questions posed to them (NSB 2008). These surveys paint a grim picture, but in fact American science literacy is fairly comparable to science literacy throughout the developed world. With the exception of questions about evolution, which might reflect American culture more than general scientific knowledge, the number of questions answered correctly tends to be on par with or better than European scores (NSB 2008). For scientists, it is disappointing and scary that many people are confused about whether humans and dinosaurs lived together. But for what it is worth, the general public also struggles to correctly answer basic questions about civics or world geography, indicating that ignorance may not be a problem unique to science.

\section{NO NEWS IS GOOD NEWS?}

Considering that Americans report that their primary source of science news is television (NSB 2008), the confusion over basic facts is not terribly surprising. If you watched 5 hours of cable news in 2007, you would likely have seen only 1 min about science and technology, $1.25 \mathrm{~min}$ about the environment, and $3.46 \mathrm{~min}$ about health and health care (PEJ 2008). On the other hand, you would have seen 10 min of celebrity news, at least 26 min on crime, and 35 min about campaigns and the election. The science news coverage on cable television is not anomalous among media outlets: science topics are only 1 to $2 \%$ of the news topics covered on network nightly news, in online news sources, and in newspapers (PEJ 2008). The paucity of science coverage is one factor that may explain why Americans have difficulty delineating science from pseudoscience (NSB 2008).

Nevertheless, Americans generally think highly of science, and turn to popular books and the internet to inform themselves about specific scientific issues they are interested in (NSB 2008). When surveyed, only $10 \%$ of Americans believe they are well informed about new scientific discoveries, but $47 \%$ of Americans report having 'a lot' of interest in science news (VCU 2006).

\section{SCIENTISTS IN THE PUBLIC FORUM}

When asked to name a science role model for kids today, only $56 \%$ of adults could do so; only $4 \%$ could name a living scientist like Stephen Hawking, and $6 \%$ named former vice-president $\mathrm{Al}$ Gore or philanthropist Bill Gates (The State of Science in America 2008). Yet confidence in scientists exceeds the level of confidence in all other institutional leaders with the exception of the military. Americans believe that science leaders are knowledgeable, impartial, and should be influential when it comes to science-related policy issues, such as global climate change or stem cell research (NSB 2008).

\section{GRADUATE SCHOOL: A PROCESS OF CULTURAL IMMERSION}

Within the scientific community, there is less of a consensus on how involved science leaders should be in policy issues and a fear that advocacy can taint the objectivity of science. Science, as a social institution, is built around a fundamental commitment to truthfulness, accuracy and objectivity. These values are taught throughout a science education, but instilled in graduate school, when a student works hard in the laboratory of an advisor and, in turn, is trained in the methodologies that ground their work in accuracy and objectivity. Students are taught that their ethical obligation as a researcher is to transparently convey what they think they know, to what degree they know it, and why they are sure.

Part of the inheritance a student receives during this process of immersion is a technical grammar and vocabulary that is appropriate and necessary for an expert. Use of descriptive metaphor is often replaced with qualifying terms whose meanings are well understood within the field of study. This language, as opposed to a common language, is preferred because the system most values professional contribution. However, it can lead to serious communication problems with the public. One example is the way the word 'theory' is used. The United States National Academy of Sciences defines 'theory' to be 'a comprehensive explanation of some aspect of nature supported by a vast body of evidence' (NAS 2008, p. 11). A 'theory' is the best that scientists have; however, the public uses the word as a synonym for speculation or mere conjecture. This sort of language has plagued communication about climate change (Hassol 2008), as scientists use words such as 'enhance' (meaning 'to increase') that the public intuitively interprets differently (for example, meaning to 'make better'). Error, bias, and risk are also words that can be interpreted differently in a scientific versus common language. 
In keeping with valuing professional contributions most highly, and because science is competitive and scientists are naturally critical colleagues, graduate students learn to think twice before sharing information. Hesitation, in situations ranging from being asked to share unpublished research at a professional meeting to a question fielded by the press, becomes an ingrained reaction. Furthermore, work on research articles supersedes other activities because promotion is often determined by one's professional publication record. This atmosphere creates a disincentive to communicate with the public.

Additionally, many scientists distrust journalists. The impression is that, in the pursuit of a 'fair and balanced' perspective, journalists are blatantly ignoring the longstanding accumulation of sound scientific evidence. More than $90 \%$ of scientists agree that few reporters understand the nature of science and technology, especially the 'tentativeness of most scientific discovery and the complexities of the results' (Hartz \& Chappell 1997, p. 29). Scientists (and especially graduate students not yet established in their field) fear misrepresentation, of which anecdotal evidence within the scientific community abounds. Being asked to comment on scientific issues that lie outside their field of expertise also may deter scientists from communicating their work to diverse audiences. In short, scientists are trained to communicate with their colleagues and are offered little incentive to step outside the arena of research.

\section{CHANGING ATTITUDES, REPAIRING RELATIONSHIPS}

The evidence suggests that the general public's scientific literacy may be insufficient for analyzing the complex issues faced by society today. In the US, there is no quick fix for the problem - an overhaul of the current educational system to improve the way science is taught in primary and secondary education seems unlikely. A more realistic short-term goal involves the way we educate 2 specific groups of people: scientists and journalists.

Journalists - I would argue all journalists, not just science and technology specialists, due to the ubiquity of science-related topics in the news-need to be more than scientifically literate. Beyond a comprehensive understanding of basic facts, exposure to the scientific method is important to give journalists perspective on the topics they cover. Understanding the variability inherent in scientific results and how to contextualize 'statistically significant' results may help journalists identify flawed studies or conclusions, and better report scientific results that can be very complex. An introduction to scientific language and thought could be integrated into journalism degrees with a requirement for coursework, including a general science course and a course on the role of science in society, and with opportunities for short internships in a research environment for journalism students that express interest. Some journalists already specialize in complex topics such as climate change (e.g. A. C. Revkin's Dot Earth blog in the New York Times, http://dotearth.blogs.nytimes.com). Through their continued reporting on the topic, they come to be trusted by the research community, can interpret breaking news based on scientific findings, and become a trusted source of information for the public. Training or recruiting more specialized journalists in diverse scientific fields may be an effective way to increase general scientific literacy.

In turn, science graduate students should be required to take a course on writing for the public - not with the intention of turning scientists into journalists, but to help them take a step back from the language they are immersed in. My experience in such a class, taught jointly by a scientist and a science journalist, was overwhelmingly positive. It became patently obvious that jargon prevents effective communication even between the students of marine biology, marine chemistry and marine geology. In this class, students were given the tools to help them identify how they can share information in terms that resonate with the public. I advocate for this training to happen earlier rather than later in a graduate education because the skills are useful; furthermore, I found that translating my research into a common language was difficult but also inherently reflective. This learning process forces students to contemplate the role their science has (or should have) in society. Simply identifying what they think is important for people to understand about their work may catalyze a change in the way young scientists think about communication and public knowledge.

\section{SCIENTISTS AND SCIENCE LITERACY IN THE FUTURE}

As a scientist, I would like to believe that, if people 'had the facts', they would come to logical conclusions supported by basic research, and that this would generate sound policy decisions. But it is not that simplethe 'facts' are only enough to frame the debate, and will not necessarily bring the public around to a scientific world-view (as demonstrated by the consistent failure of Americans to correctly answer basic survey questions about evolution). So scientists should focus their energy on doing what they are good at and know best — doing science. 
The responsibility scientists have to society is to acknowledge that their work does not happen in a bubble. First, scientists should be aware of the public's expectations and fears regarding scientific topics in their particular discipline (e.g. popular perceptions of cloning or of the prediction of natural disasters). Then, they should extend their commitment to truthful, accurate and objective communication to include professionals beyond their immediate discipline who share common goals - be they other earth scientists, social scientists, or humanitarians. With these groups, scientists can advocate for and contribute to a scientific understanding of what shapes public knowledge and decision making. For example, recent research (by an economist) shows that a faulty mental model of accumulation has led an educated public (a sample of graduate students at MIT) to serious errors in their reasoning about climate change (Sterman 2008). Climate scientists should be aware of this when they present their results to other scientists and to journalists. Particularly in disciplines involving risk analysis, scientists and journalists need a solid understanding of how people interpret science.

Another important part of doing science that can be overlooked is involving the public stakeholders. Helping this demographic understand the significance of the questions being asked in turn helps them to understand the results. When scientists understand and can explain how their science fits into the world at large, everyone benefits.

Ultimately, increasing the public understanding of science will require investments of time and money -

Editorial responsibility: Virginia Burkett, Many, Louisiana, USA in schools, in media, in science-but the returns, for society and for the planet, will be high.

\section{LITERATURE CITED}

Hartz J, Chappell R (1997) Worlds apart: how the distance between science and journalism threatens America's future. First Amendment Center, Nashville, TN. Available at www.freedomforum.org/publications/first/worldsapart/ worldsapart.pdf

Hassol S (2008) Improving how scientists communicate about climate change. Eos Trans Am Geophys Union 89:106-107

Kennedy D (2007) Approaching Science. Science 318:715

NAS (National Academy of Sciences) (2008) Science, evolution and creationism. Available at: www.nap.edu/sec

NSB (National Science Board) (2008) Chapter 7: Science and technology public attitudes and understanding. Science and Engineering Indicators 2008. Available at www.nsf. gov/statistics/seind08/

Pagels H (1989) The dreams of reason. Simon \& Schuster, New York

PEJ (Project for Excellence in Journalism) (2008) The state of the news media 2008: An annual report on American journalism. Available at www.stateofthenewsmedia.org/2008/

Sterman JD (2008) Risk communication on climate: mental models and mass balance. Science 322:532-533

The State of Science in America (2008) Einstein may outrank Britney Spears but survey shows science education needs help in United States. Museum of Science and Industry Chicago, IL. Available at www.harrisinteractive.com/ NEWS/newsletters/clientnews/2008_ChicagoMuseum. pdf

VCU (Virginia Commonwealth University Life Sciences Survey) (2006). Opinions shifting on stem cell research; opposition to cloning continues life sciences survey. VCU Center for Public Policy, Richmond, VA. Available at www. vcu.edu/lifesci/images2/ls_survey_2006_report.pdf

Submitted: December 15, 2008; Accepted: March 13, 2009

Proofs received from author(s): March 23, 2009 